\title{
ナノテクノロジーが拓く新たな超音波診断・治療技術
}

鈴木 亮, ${ }^{a}$ 小田雄介, ${ }^{a}$ 小俣大樹, ${ }^{a}$ 澤口能一, ${ }^{a}$ 根岸洋一, ${ }^{b}$ 丸山一雄 $*, a$

\section{Novel Dianostics and Therapeutics with Ultrasound Technologies and Nanotechnologies}

\author{
Ryo Suzuki, ${ }^{a}$ Yusuke Oda, ${ }^{a}$ Daiki Omata, ${ }^{a}$ Yoshikazu Sawaguchi, ${ }^{a}$ \\ Yoichi Negishi, ${ }^{b}$ and Kazuo Maruyama ${ }^{*, a}$ \\ ${ }^{a}$ Laboratory of Drug and Gene Delivery System, Faculty of Pharma-Sciences, Teikyo University; \\ 2-11-1 Kaga, Itabashi-ku, Tokyo 173-8605, Japan: and Department of Drug Delivery and \\ Molecular Biopharmaceutics, School of Pharmacy, Tokyo University of Pharmacy and \\ Life Sciences; 1432-1 Horinouchi, Hachioji, Tokyo 192-0392, Japan.
}

(Received August 20, 2013)

\begin{abstract}
Ultrasound is a good tool for theranostics due to have multi-potency both of diagnostics with sonography and therapeutics with high intensity focused ultrasound (HIFU). In addition, microbubbles and nanobubbles are utilized as not only contrast imaging agent but also enhancer of drug and gene delivery by combination of ultrasound. Recently, we developed novel liposomal nanobubbles (Bubble liposomes) which were containing perfluoropropane. Bubble liposomes induced jet stream by low intensity ultrasound exposure and resulted in enhancing permeability of cell membrane. This phenomenon has been utilized as driving force for drug and gene delivery. On the other hand, the combination of Bubble liposomes and high intensity ultrasound induces strong jet stream and increase temperature. This condition can directly damage to tumor cells, we are applying this for cancer therapy. Therefore, their combination has potency for various cancer therapies such as gene therapy, immunotherapy and hyperthermia. In this review, we discuss about cancer therapy by the combination of Bubble liposomes and ultrasound.
\end{abstract}

Key words — cancer therapy; ultrasound; liposome

\section{1. はじめに}

近年, “Therapeutics（治療）”と“Diagnostics (診断)”を合わせた新たな言葉 “Theranostics（セ ラノスティクス)”が注目されている。この言葉は 文字通り治療と診断を同時に行うシステムを示して いる.この言葉の出現の背景には, 診断・治療のた めの医療機器の技術革新がある. 現在, X 線 computed tomography (CT), magnetic resonance imaging (MRI), positron emission tomography (PET), 超音波などの診断用装置が臨床応用されている。 そ の中で超音波造影装置は，管理区域が不要，小型で ベッドサイドにも運搬可能, 比較的安価, リアルタ イムイメージングが可能などの多くの利点があり注

The authors declare no conflict of interest.

$a$ 帝京大学薬学部（干173-8605 東京都板橋区加賀 2-11 $-1), b$ 東京薬科大学薬学部（广192-0392 東京都八王子 市堀之内 1432-1)

*e-mail:maruyama@ @ pharm.teikyo-u.ac.jp 本総説は, 日本薬学会第 133 年会シンポジウム S30203 で発表した内容を中心に記述したものである.
目されている. また，最近では標的部位に体外から ピンポイントに超音波のエネルギーを集束できる治 療用超音波装置〔強力集束超音波 (high intensity focused ultrasound; HIFU)] が開発され，新たなが ん治療法として期待されている。このように超音波 は，治療と診断のための装置が揃っており， セラノ スティクスを構築する上で有望な医療用エネルギー として捉えられる.

これまでに筆者らは，セラノスティクスの構築を 目的にリポソーム技術を駆使した新たなナノバブル 〔バブルリポソーム $(500 \mathrm{~nm})$ を開発した（Fig. 1). ${ }^{1-4)}$ このバブルリポソームは既存のマイクロバ ブルであるソナゾイドより小さいことが明らかとな つている．バブルリポソームに超音波を照射する と, 超音波の周波数や強度に応じてバブルリポソー ムが振動したり圧壊したりと様々な振る舞いをす る。例えば，超音波造影装置でのイメージング超音 波ではバブルリポソームは振動し，イメージング輝 度を増強させる。 また, 超音波照射強度の高い治療 


\section{Bubble liposome}

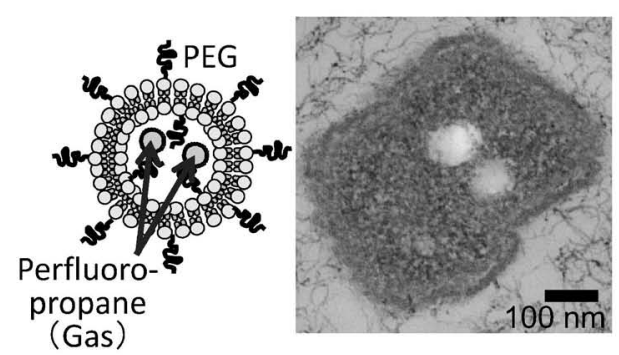

Shell

Lipid from liposome Mean diameter: $500 \mathrm{~nm}$

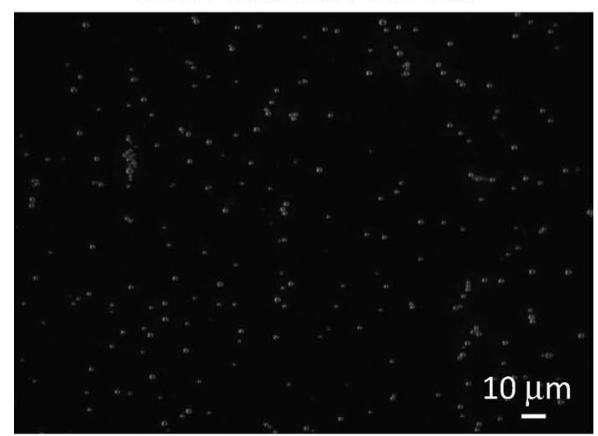

Sonazoid

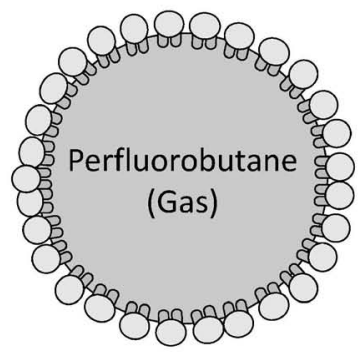

Shell

Phosphatidylserine

Mean diameter: $2-3 \mu \mathrm{m}$

Fig. 1. Comparison of Bubble Liposomes and Conventional Microbubbles (Sonazoid)

用超音波照射では，バブルリポソームの圧壊が誘導 される，このときにジェット流が生じるが，このエ ネルギーを駆動力として細胞内や組織への薬物・遺 伝子デリバリーを行うことができる（Fig. 2). ${ }^{5-7)}$ さらに高強度の超音波を照射するとさらに激しいジ エット流とともに熱が生じる。この現象を利用する ことでがん細胞を直接傷害するがん温熱療法を構築 することができる.このようにバブルリポソーム は，超音波を用いた診断・治療の可能性を最大限に 発揮するための有望なツールになるのではないかと 考えている。 そこで本稿では，バブルリポソームと 超音波照射の併用によるがん治療戦略に関して筆者 らの取り組みを紹介する。

2. 超音波を利用した抗原デリバリー

樹状細胞（dendritic cell; DC）を用いたがん免疫 療法はがん細胞特異的な細胞傷害性を誘導可能であ ることから，副作用の少ない低侵襲的な治療法とし て期待されている．高い治療効果を得るためには DC の major histocompatibility complex (MHC) クラス I 抗原提示を介してがん細胞に対する細胞傷 害性 T 細胞（cytotoxic T lymphocyte; CTL）を誘 導することが重要である。しかし，DC にがん抗原 をそのまま作用させても効率よく MHC クラス I

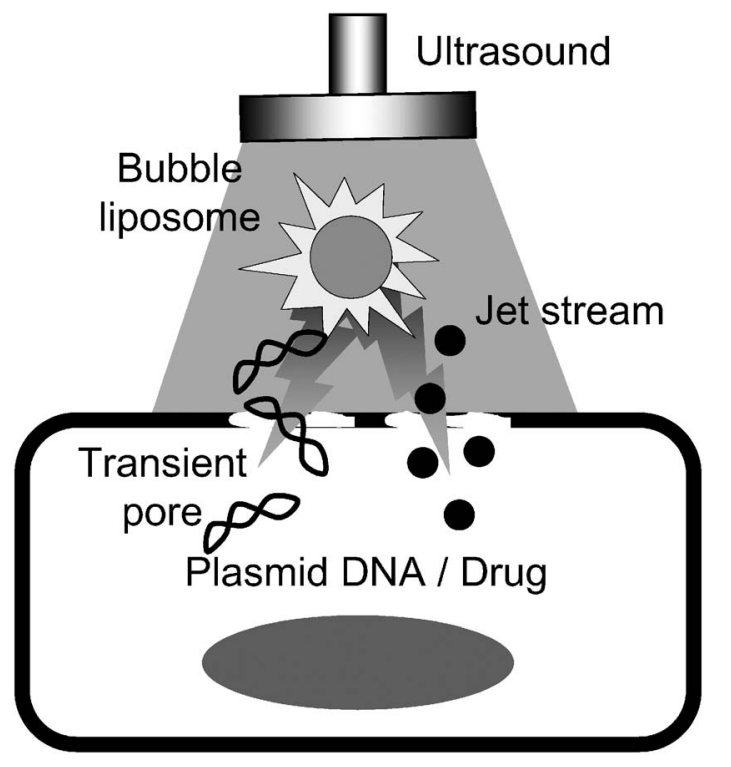

Fig. 2. Drug/Gene Delivery System with Bubble Liposome and Ultrasound Exposure

抗原提示は誘導されず，有効な抗腫瘍免疫を誘導す ることは困難とされている，一方で，DC の細胞質 内に抗原を存在させることができれば MHC クラ ス I 抗原提示を誘導可能と考えられている。 そこで 筆者らは，バブルリポソームと超音波を利用した DC 細胞質内への抗原デリバリー技術の確立を試み 
た。 ${ }^{8)}$ マウス骨髄由来 DC にバブルリポソームとモ デル抗原としてニワトリ卵白アルブミン（ovalbumin；OVA）を添加し，超音波照射することで抗原 を送達した。 その後，この DC を $\mathrm{MHC}$ クラス I 拘束性 OVA エピトープを認識し，IL-2 を産生する CD8-OVA1.3 細胞と共培養し，培養上清に含まれ るインターロイキン-2（IL-2）を測定した（Fig. 3). その結果，OVA を添加しただけの群では IL-2 産生 は低レベルだったのに対し，バブルリポソームと超 音波により OVA を送達した群では高い IL-2 産生 が認められた。これは，バブルリポソームと超音波 により細胞質に直接導入された抗原があたかも DC の内在性抗原かのように認識されて MHC クラス I に抗原提示されたためと考えらえた．また，抗原 送達した DC をマウスに免疫することで抗原特異的 な CTL を誘導可能であり，有効な抗腫瘍効果が得 られることを確認した（Fig. 4)。これらのことか ら，バブルリポソームと超音波の併用は DCへの抗 原デリバリーシステムとして応用可能になると期待 される.9

\section{3. 超音波遺伝子デリバリー}

近年，抗腫瘍免疫の活性化を目的とした新しいが ん治療法としてサイトカイン療法が注目されてい る.その中でもインターロイキン-12 (IL-12) は, ナチュラルキラー（NK）細胞や細胞傷害性 $\mathrm{T}$ 細胞 などを活性化することで強力な抗腫瘍効果を誘導す

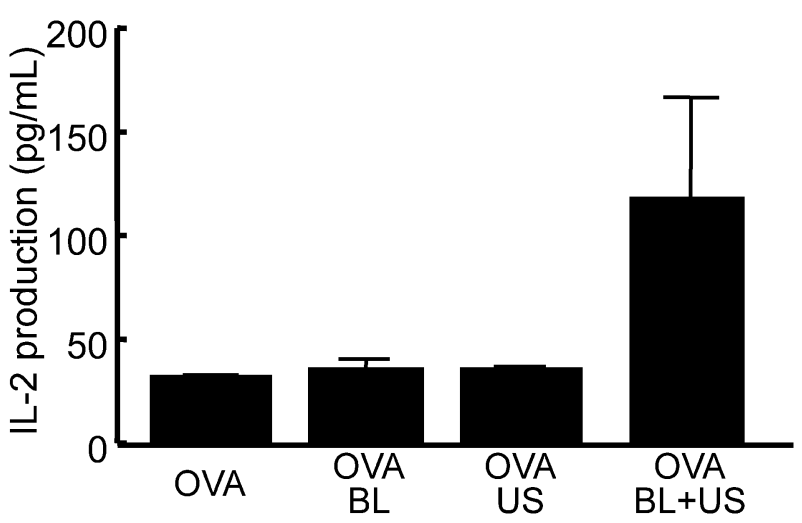

Fig. 3. MHC Class I Restricted Ovalbumin Presentation after Ovalbumin Delivery into Dendritic Cells Using a Combination of Bubble Liposomes and Ultrasound Exposure

Dendritic cells (DCs) were pulsed with ovalbumin (OVA) alone or OVA in conjunction with ultrasound (US) exposure and/or Bubble liposomes (BL). After US exposure, the DCs were incubated for $1 \mathrm{~h}$ at $37^{\circ} \mathrm{C}$, then washed with PBS. After culturing for $24 \mathrm{~h}$, the DCs were co-cultured with CD8-OVA1.3 cells for $20 \mathrm{~h}$. The concentration of IL-2 in the supernatants was measured.
るサイトカインとして，臨床の場においても期待さ れている。しかし，IL-12 の全身投与は，全身作用 による副作用のリスクが懸念されており，副作用の 影響なく治療効果を得るためには，がん組織特異的 に IL-12 を作用させる必要がある. 10) バブルリポ ソームと超音波照射の併用は，in vivo でも効率よ く遺伝子導入できることが明らかとなっている。 そ こで筆者らは，バブルリポソームと超音波の併用に よる IL-12 発現プラスミド DNA（pCMV-IL12）の 遺伝子導入によるがん遺伝子治療を試みた. ${ }^{11)}$ マウ 又卵巣がん由来細胞（OV-HM）を移植したマウス のがん組織に pCMV-IL12 とバブルリポソームを投 与し，超音波照射 $\left(1 \mathrm{MHz}, 0.7 \mathrm{~W} / \mathrm{cm}^{2}, 1\right.$ 分間) することでがん組織に遺伝子導入した．その後，腫 瘍径を指標に抗腫瘍効果を評価した（Fig. 5)。そ の結果，バブルリポソームと超音波の併用により pCMV-IL12 を導入した群で顕著な腫瘍増殖抑制効 果が認められた。一方，Lipofectamine 2000 による 遺伝子導入では，ほとんど腫瘍増殖抑制効果は認め られなかった。このような結果が得られたのは，バ ブルリポソームと超音波の併用により効率よく IL-12 遺伝子が発現し，強力な抗腫瘍免疫が誘導さ れたためであると考えられた。このことから，バブ ルリポソームと超音波照射の併用法は IL-12 がん遺 伝子治療において有用な非ウイルスベクターになる ことが示唆された。

\section{4. 超音波がん温熱療法}

バブルリポソームのキャビテーション誘導は, HIFU 治療で利用されている超音波エネルギーより

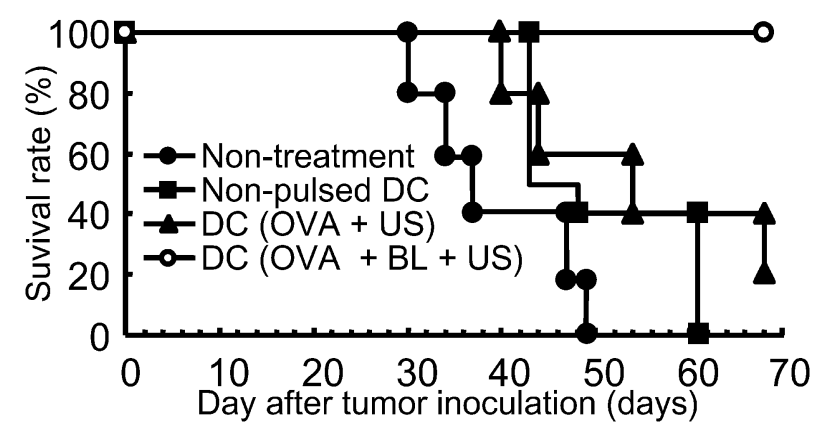

Fig. 4. Antitumor Effect Caused by Immunization of Dendritic Cells Treated with Antigen, Bubble Liposomes and Ultrasound Exposure

C57BL/6 mice were immunized with DCs twice. Seven days after the second immunization, E.G7-OVA cells were intradermally inoculated into the backs of the mice, and survival of the mice was monitored. 


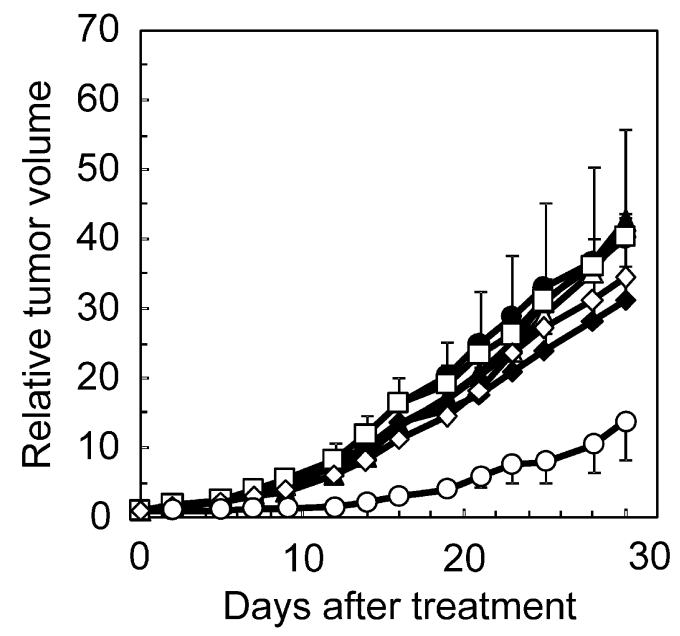

Control

$\triangle \mathrm{pCMV}-\mathrm{IL} 12$

$\leftarrow \mathrm{pCMV}-\mathrm{IL} 12+\mathrm{BL}$

PCMV-IL12 + US

-O- pCMV-IL12 + BL + US

$-\square-\mathrm{pCMV}-\mathrm{Luc}+\mathrm{BL}+\mathrm{US}$

$\prec$ pCMV-IL12 + LF2000

Fig. 5. Anti-tumor Effect of IL-12 Gene Delivery

B6C3F1 mice were intradermally inoculated with $1 \times 10^{6} \mathrm{OV}-\mathrm{HM}$ cells into the flank. After 7 days, the tumors were injected with pCMV-IL12 (10 $\left.\mu \mathrm{g}\right)$ using Bubble liposomes (BL) $(2.5 \mu \mathrm{g})$ and/or ultrasound (US) $\left(1 \mathrm{MHz}, 0.7 \mathrm{~W} / \mathrm{cm}^{2}, 1 \mathrm{~min}\right)$, or Lipofectamine 2000 (LF2000) as a conventional lipofection method. The volume of the growing tumors was calculated by: (tumor volume; $\left.\mathrm{mm}^{3}\right)=($ major axis; $\mathrm{mm}) \times(\text { minor axis; } \mathrm{mm})^{2} \times 0.5$. The data are represented as tumor volume relative to the tumor volume on the day of treatment (day 7 after tumor inoculation).

はるかに低い強度で誘導可能である。 そのため, こ のバブルリポソームを利用することで，比較的低い 超音波強度でもバブルリポソームのキャビテーショ ンに伴い生じるソノポレーション効果や発熱が誘導 可能になる。そのため, HIFUより低強度の超音波 照射でがん治療効果を得ることができると期待され る.そこで，バブルリポソームと超音波を利用した がん温熱療法の可能性について検討した.

一般に温熱処理による細胞致死効果は $42.5^{\circ} \mathrm{C}$ を 境目に $1^{\circ} \mathrm{C}$ の温度上昇によって, 劇的に増加（数百 倍に殺細胞効果が上昇）することが知られてい る. ${ }^{12,13)}$ そのため, バブルリポソームのキャビテー ション誘導による温度上昇が細胞傷害に関与すると 考えられる，そこでマウス大腸がん由来細胞（Colon-26）を移植したマウスのがん組織内にバブルリ ポソームを投与後, そのがん組織に超音波照射（1 $\mathrm{MHz}, 4 \mathrm{~W} / \mathrm{cm}^{2}, 2$ 分間）し，がん組織内の温度上 昇を評価した（Fig. 6)。 その結果，がん組織に超 音波のみを照射した場合，がん組織内温度は約 $38.5^{\circ} \mathrm{C}$ (約 $5.5^{\circ} \mathrm{C}$ 上昇) となった。 また，バブルリ ポソーム存在下で超音波を併用すると，がん組織内 温度が約 $44^{\circ} \mathrm{C}$ （約 $11^{\circ} \mathrm{C}$ 上昇）に達した。このがん 組織内の温度上昇は，バブルリポソームのキャビ テーション誘導に伴うものであり，がん組織内温度 上昇による温熱効果とジェット流によるソノポレー ション効果により，がん細胞死が誘導可能になると 考えられた。 そこで，このバブルリポソームと超音

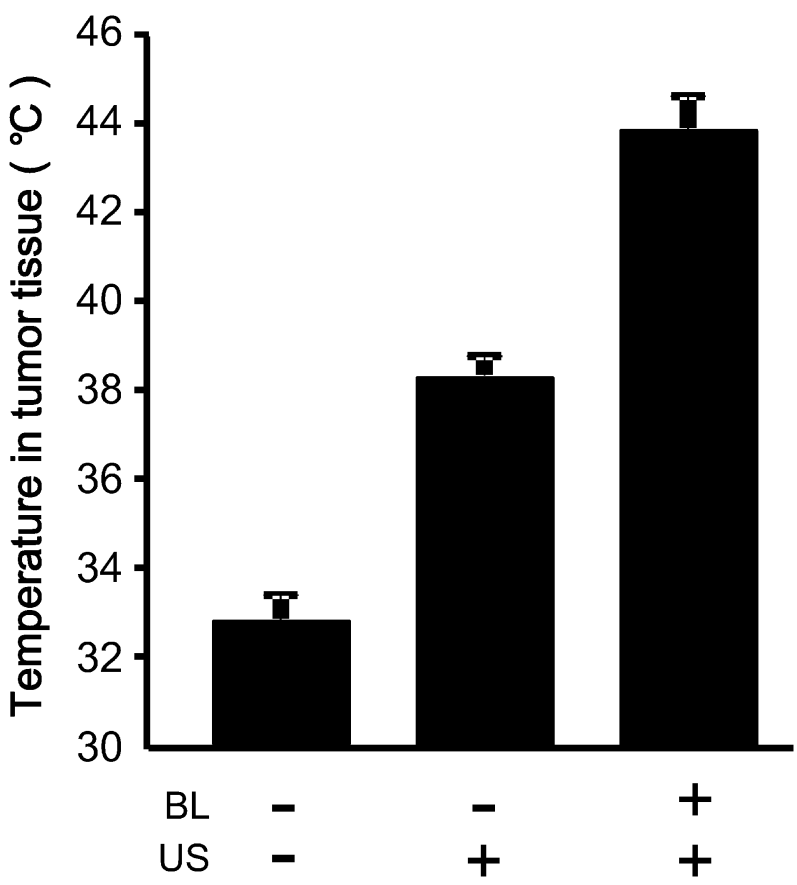

Fig. 6. Temperature in the Tumor Tissue Increases with Ultrasound Exposure to Bubble Liposomes

Colon- 26 cells $\left(1 \times 10^{6}\right.$ cells $)$ were subcutaneously inoculated into mice. After $8 \mathrm{~d}$, Bubble liposomes (BL) were injected into the tumor tissue. The tissue was then transdermally exposed to ultrasound (US) ( $1 \mathrm{MHz}, 4 \mathrm{~W} /$ $\left.\mathrm{cm}^{2}, 2 \mathrm{~min}\right)$. To measure the temperature in the tumor tissue, a thermocouple was inserted into the tumor tissue. In this case, the data shows the temperature at $2 \mathrm{~min}$ from the start of ultrasound exposure.

波の併用によるがん治療効果を検討した。その結 果，超音波単独で治療した群では，ほとんどがん細 胞の増殖抑制が認められなかった。一方，バブルリ ポソームと超音波の併用群では，顕著ながん細胞の 


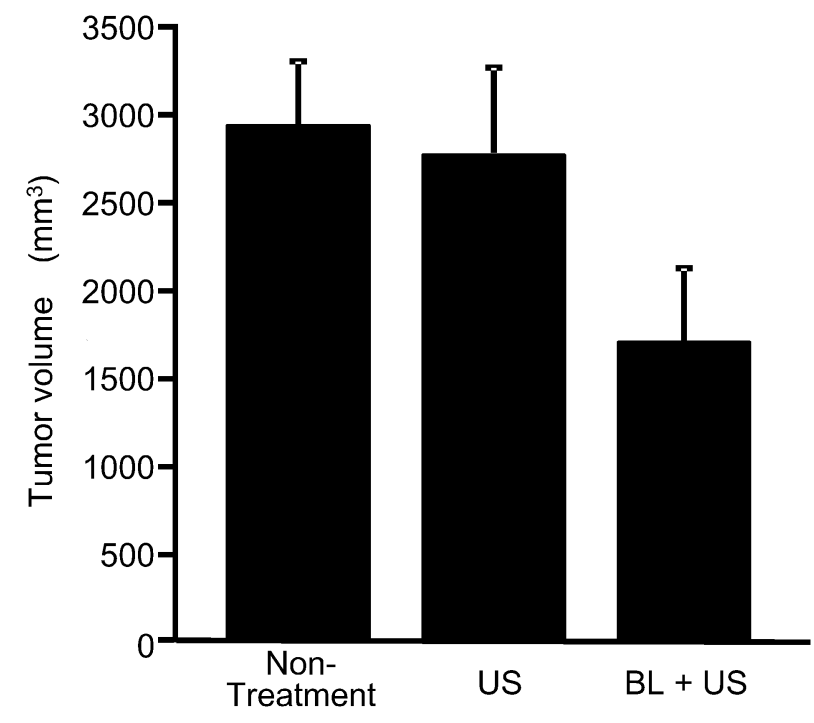

Fig. 7. Tumor Growth is Suppressed by Ultrasound Exposure to Bubble Liposomes

Colon- 26 cells $\left(1 \times 10^{6}\right.$ cells $)$ were subcutaneously inoculated into mice. After $8 \mathrm{~d}$, Bubble liposomes (BL) were injected into the tumor tissue. The tissue was then transdermally exposed to ultrasound (US) $(1 \mathrm{MHz}, 4 \mathrm{~W} /$ $\mathrm{cm}^{2}, 2 \mathrm{~min}$ ). Tumor growth was assessed by measuring the tumor volume. The tumor volume was measured at $27 \mathrm{~d}$ after tumor inoculation.

増殖抑制効果が認められた（Fig. 7)。このように, バブルリポソームと超音波の併用は，HIFU より低 強度の超音波照射で，がん細胞を熱とジェット流で 直接傷害可能な新たながん温熱療法として期待され る.

\section{5. おわりに}

本稿では，バブルリポソームと超音波を利用した 新たながん治療戦略について紹介した。がんに対す る治療法が多様化していく中で，がん治療用薬物と しての可能性を秘めた低分子化合物，抗原，遺伝子 など様々な分子を細胞内に送達することのできる技 術を確立することは非常に重要であると考えられ る、それゆえ，本稿で紹介したバブルリポソームと 超音波の併用による新たなドラッグデリバリーシス テム（DDS）技術は革新的がん治療システムを構 築するための基盤技術になるものと期待される。さ らに，DDS に利用する超音波強度より高い強度の 超音波とバブルリポソームの併用によるがん温熱治 療への応用の可能性も見い出すことができた。今 後, 副作用の少ない理想的ながん診断・治療システ ムの構築に向けて, バブルリポソームへのパッシブ ターゲティングやアクティブターゲティング能の付 与による体内動態制御を行っていきたいと考えてい る.さらに，集束超音波技術を駆使して超音波照射
部位の空間的制御を組み合わせたダブルターゲティ ングにより厳密な時間的・空間的制御を可能とする がんに対する超音波セラノスティクスの開発に取り 組んでいきたいと考えている.

\section{謝辞＼cjkstart本研究に関する実験について，ご指導，} ご助言を賜りました国立がんセンター東病院 松村 保広先生, 京都大学大学院薬学研究科 橋田 充先 生, 山下富義先生, 樋口ゆり子先生, 長崎大学大学 院医歯薬学総合研究科 川上 茂先生, 大阪大学大 学院薬学研究科 中川晋作先生, 岡田直貴先生, 福 岡大学医学部 立花克郎先生, 北海道大学大学院情 報科学研究科 工藤信樹先生, 防衛医科大学校 萩沢 康介先生に感謝申し上げます。また本実験の遂行に おいて, ご協力頂きました帝京大学薬学部薬物送達 学研究室の学生諸子にお礼申し上げます。なお，本 研究の一部は, 独立行政法人医薬基盤研究所保健医 療分野における基礎研究推進事業及び先駆的医薬 品・医療機器研究発掘支援事業, 文部科学省科学研 究費補助金基盤研究 $(\mathrm{C})$, 厚生労働省科学研究費 補助金第 3 次対がん総合戦略研究事業により遂行さ れたものです.

\section{REFERENCES}

1) Suzuki R., Takizawa T., Negishi Y., Hagisawa K., Tanaka K., Sawamura K., Utoguchi N., Nishioka T., Maruyama K., J. Control. Release, 117, 130-136 (2007).

2) Kodama T., Tomita N., Horie S., Sax N., Iwasaki H., Suzuki R., Maruyama K., Mori S., Manabu F., J. Electron Microsc. (Tokyo), 59, 187-196 (2010).

3) Suzuki R., Takizawa T., Negishi Y., Utoguchi N., Sawamura K., Tanaka K., Namai E., Oda Y., Matsumura Y., Maruyama K., J. Control. Release, 125, 137-144 (2008) .

4) Kodama I., Suzuki R., Maruyama K., Toyama J., Br. J. Pharmacol., 114, 503-509 (1995).

5) Suzuki R., Oda Y., Utoguchi N., Maruyama K., J. Control. Release, 149, 36-41 (2011) .

6) Sonoda S., Tachibana K., Yamashita T., Shirasawa M., Terasaki H., Uchino E., Suzuki R., Maruyama K., Sakamoto T., $J$. Ophthalmol., 2012, 412752 (2012). 
7) Ueno Y., Sonoda S., Suzuki R., Yokouchi M., Kawasoe Y., Tachibana K., Maruyama K., Sakamoto T., Komiya S., Cancer Biol. Ther., 12, 270-277 (2011).

8) Suzuki R., Oda Y., Utoguchi N., Namai E., Taira Y., Okada N., Kadowaki N., Kodama T., Tachibana K., Maruyama K., J. Control. Release, 133, 198-205 (2009).

9) Oda Y., Suzuki R., Otake S., Nishiie N., Hirata K., Koshima R., Nomura T., Utoguchi N., Kudo N., Tachibana K., Maruyama K., J. Control. Release, 160, 362-366 (2012).

10) Kanagawa N., Gao J. Q., Motomura Y.,
Yanagawa T., Mukai Y., Yoshioka Y., Okada N., Nakagawa S., Biochem. Biophys. Res. Commun., 372, 821-825 (2008).

11) Suzuki R., Namai E., Oda Y., Nishiie N., Otake S., Koshima R., Hirata K., Taira Y., Utoguchi N., Negishi Y., Nakagawa S., Maruyama K., J. Control. Release, 142, 245250 (2010).

12) Roti Roti J. L., Int. J. Hyperthermia, 24, 3-15 (2008).

13) Dewey W. C., Hopwood L. E., Sapareto S. A., Gerweck L. E., Radiology, 123, 463-474 (1977). 